\title{
4. Romanister utan doktorshatt: Om Arne Lundgren och några av hans samtida i Göteborg
}

\author{
Anna Svensson
}

\subsection{Inledning}

I historieskrivningen om Göteborgs universitet, GU, och dess föregångare Göteborgs högskola är Romanska språks historia främst dess professorers, exempelvis hos Lindberg och Nilsson (1996), Nilsson (1996b) och Söhrman (2016). López Serrano (2013) har ett bredare perspektiv i sin artikel om hispanismen i Sverige. Om Handelshögskolan i Göteborg ägnar tidigare rektorn Hadar Berglund i sin minnesbok halva kapitlet över skolans språklärare åt Iberoamerikanska institutet och dess verksamhet, ett tecken på det förtroende och stora tillgivenhet han hyste för dess grundare Nils Hedberg (1903-1965) (Berglund \& Grönfors 1977). I årsberättelserna, katalogerna och arkiven hittar vi dock förutom Hedberg återkommande namn som Matilde Goulard (1910-1998), Börje Cederholm (1912-1972) och Arne Lundgren (1925-2011). Gemensamt för dessa är att de stod för en substantiell del av undervisningen i och utvecklingen av portugisiska och spanska i högre utbildning i Göteborg från 1940-talet och framåt, men också att de inte var disputerade; såväl Hedberg som Lundgren skulle dock bli hedersdoktorer 1964 respektive 1991, medan Cederholm och Goulard inte hedrades med denna utmärkelse. ${ }^{28}$ I det följande vill jag sätta ljuset på några av dessa som av olika anledningar och i varierande utsträckning blev diversearbetare i språk och litteratur inom och utom akademin, med särskild betoning på Lundgren då mitt syfte också är att göra innehållet i hans arkiv känt. Det kom till Göteborgs universitetsbibliotek, GUB, efter hans död 2011 och består av drygt fem hyllmeter innehållande anteckningar, en del manus och korrekturläsningar, korrespondens, urklipp, bokbeställningar och vanligen även kopior på Lundgrens egna brev. Genom stickprov i arkivet,

28 I den av GU utgivna skriften om dess hedersdoktorer förs av Olsson (2007:137) främst Lundgrens skönlitterära författarskap fram. I förslagsställarna Sverker Göranssons och Lars Lindvalls motivering (1990) betonas däremot hans översättar- och introduktörsgärning starkare och även hans insatser inom utbildning framhålls. 
som inte är förtecknat, ger jag exempel på material som rör Lundgren som student och lärare vid Handelshögskolan och GU, samt som översättare och introduktör. ${ }^{29}$

\subsection{Spanskundervisningen vid Göteborgs högskola och GU}

Uppenbarligen var det länge brist på lärare med doktorsexamen i portugisiska eller spanska, själv hade jag som student 1979/80 nio lärare varav endast en disputerad och då hade ändå Romanska språk sedan 1961 varit uppdelat som examensämne i respektive språk och spanska funnits som försöksverksamhet och senare valbart ämne i studentexamen sedan mer än tre decennier. Franskans dominans som examens- och disputationsämne påverkade troligen situationen negativt för de andra språken alltför länge. Vi kan fråga oss som Lundgren i samband med Gunnar von Proschwitz (1922-2005) disputation 1956, vad man skulle med alla franska docenter till när det inte fanns så många studenter, de andra romanska språken borde fått ta mer plats (Lundgren 1956d). En sammanfattning av läget för spanskan i högre utbildning presenterades av Matilde Goulard och Max Gorosch (1912-1983) vid Riksföreningen för lärarna i moderna språks årsstämma 1952 och publicerades av Gorosch i årsskriften (1953). Märkas kan att spanska i Göteborg och Uppsala inte kunde ingå i fil. ämbetsexamen dvs. i fil.mag., men däremot i betyg 2 och 3 för fil.kand. eller fil.lic. Det påpekades att i Göteborg och Uppsala fanns större möjligheter att studera modernt språk i licentiatkurserna än vid andra lärosäten. Vid en jämförelse med Skolöverstyrelsens kursanvisningar från 1952 konstaterade Gorosch att då "räcker spanska kursen i akademisk primärexamen inte alls till ens för första årets spanska i läroverken" (Gorosch 1953: 41).

Under Högskolans första decennier var språkundervisningen i hög utsträckning antingen professorns uppgift eller en utländsk lektors vad gällde

29 Citaten ur Arne Lundgrens brev publiceras med tillstånd från hans efterlevande. Iberoamerikanska institutets arkiv fram till 2007 finns i GU:s centrala arkiv (arkivnr 94) och är ordnat i serier för inkommande och utgående korrespondens med namnregister i varje årgång; det innehåller också en omfattande samling pressklipp; material för de tidigaste åren fram till och med 1942 finns i Handelshögskolans arkiv på Landsarkivet i Göteborg, SE/GLA/14137. Om inte annat anges kommer informationen om Handelshögskolans, Högskolans och GU:s kurser och anställda från respektive tryckta årsberättelser och kataloger, Severin Hallbergs Göteborgs högskolas matrikel 1916-1941 (1942) samt från Ingmar Nilssons (1996a) Göteborgs universitet 1891-1995: data över professorer, docenter, avhandlingar och befordringsärenden. Handelshögskolans årsberättelser innehåller även Iberoamerikanska institutets. 
praktisk språkanvändning, men med tiden tillkom docenter av olika slag (Lindberg \& Nilsson 1996:61 ff.). För spanskans del dröjde det till 1974 innan Per Rosengren (1933-2006) blev den förste docenten och till 1993 tills en professor var på plats, då den professur i spanska som inrättades 1981 till slut tillträddes av Ken Benson (f 1956). Innan dess hade visserligen flera av de professorer som verkade inom Högskolan och GU, varav vissa även undervisade eller examinerade på Handelshögskolan, intresserat sig för andra språk än franska (Söhrman 2016). Av docenterna kan nämnas lektorn vid Hvitfeldtska högre allmänna läroverket Gunnar Ahlborn (1903-1978), som disputerade i franska 1946 och som såväl 1951 som 1953 var i Spanien för språkstudier. Under flera år var han examinator i spanska och dyker också upp i katalogerna som lärare, framför allt på 1960-talet. Men om vi summerar uppgifterna i Nilsson (1996a) talar siffrorna sitt tydliga språk. Mellan 1907 och 1995 lades 29 doktorsavhandlingar i franska fram, 6 i spanska, 3 i italienska och 2 i provensalska. För licentiatavhandlingarna är siffrorna ännu sämre för spanskans räkning med 4 stycken mot $35 \mathrm{i}$ franska och $8 \mathrm{i}$ italienska; det tillkommer en handfull jämförande i romanska språk samt om provensalska, anglo-normandiska och katalanska. Den första av de spanska licentiatavhandlingarna kom 1948 och den första doktorsavhandlingen dröjde till Per Rosengrens 1974; i italienska hade två doktorsavhandlingar lagts fram långt tidigare, 1950 och 1953. Flitige läroboksförfattaren Sven Bjellerup (1922-2005) lade fram en licentiatavhandling om portugisiskt futurum 1949. En delförklaring till att italienskan fick ett tidigare genomslag i avhandlingsstatistiken kan vara den italienska lektorfonden som instiftades 1931 av Anna Ahrenberg (1861-1948). Genom hennes tidigare gåvor fanns från 1928 kontinuerligt en italiensk lektor medan spanskan fick nöja sig med en e.o. lärare 1928-1930, Ramón Iglesia y Parga (1905-1948) som också undervisade på Handelshögskolan. Efter fyra års vakans tillträdde Carlos Oroz (f 1903) som lektor 1934-1940 tack vare en donation av direktörerna Elof Hansson (1869-1955) och Torsten Odqvist (1883-1964). ${ }^{30}$

30 Iglesia y Parga återvände till Spanien 1930. Efter en tid vid Biblioteca Nacional fortsatte han så småningom sina studier i historia. Efter spanska inbördeskriget levde han i exil i Mexiko och USA (Bernabéu Albert 2005). Carlos Oroz blev senare legationssekreterare i Stockholm och drev företaget Spanska Importbolaget som Hedberg använde för bokinköp (Handelshögskolan i Göteborg 1923-1960). 
Efter Oroz upprätthöll först Nils Hedberg och från hösten 1943 Matilde Goulard spanskundervisningen parallellt med tjänster på Handelshögskolan, dit Hedberg kom som lärare i spanska 1931 och Goulard vårterminen 1943, som hans ersättare när han i samband med Amerikautredningen 1943 fick uppdraget som pressattaché i Buenos Aires (Svensson 2018). ${ }^{31}$ Under åren som lärare och parallellt med att han också blev Rektors sekreterare på Handelshögskolan 1933 avlade Hedberg en fil. lic.-examen i Romanska språk med avhandlingen A propos kat. avinguda: något om gatubenämningen i städer på Pyreneiska halvön. Goulard hade en "Licenciatura en Filosofía y Letras" i spanska språket och litteraturen från 1936 avlagd vid Facultad de Filosofía y Letras vid Universidad Central i Madrid, en progressiv studiemiljö starkt dominerad av kvinnor (Rodríguez López 2008). Goulard var kvar vid GU under olika benämningar - lektor, lärare, utländsk lektor, vik. universitetslektor - till början av 1980-talet. Hon var också Iberoamerikanska institutets föreståndare 1967-1977.

\subsection{Handelshögskolan och Iberoamerikanska institutet}

Det Iberoamerikanska institut som Hedberg med stöd av det göteborgska näringslivet grundat vid Handelshögskolan 1939, blev ett nav kring vilket flera av de aktiviteter som Goulard, Cederholm och Lundgren utvecklade utspann sig. ${ }^{32}$ Handelshögskolan hade från starten 1923 en stark språkprofil och erbjöd undervisning i engelska, franska, tyska och ryska. Redan i SKF-direktören och politikern Axel Carlanders (1869-1939) motion till Handelskammaren i Göteborg 1906 angående inrättandet av en handelshögskola, nämns språkundervisning och han påpekar att det vid Göteborgs högskola finns kompetens i engelska, tyska och de romanska språken (återgiven i Berglund \& Grönfors 1977: 315-319). I Handelshögskolans examensordning fordrades prövning i två språk, den långa kursen som motsvarade två års studier och en kortare praktisk kurs motsvarande ett års studier. I växande utsträckning kom båda kurserna att betona såväl språkfärdighet som realia,

31 Om Hedberg se även: Goulard (1969-1971) och Svensson (2008), om Goulard även Baeckström (1966) och Rosengren (1999). Matilde Goulard använde också namnformerna Goulard de la Lama, Goulard de Westberg och Goulard-Westberg.

32 Institutets namnform har växlat en del genom åren. Till att börja med omnämns det som Bibliotekets avdelning för spanska språket (Ibero-amerikanska institutionen). Från 1945 och fram till mitten av 1990-talet användes namnet lbero-amerikanska institutet, därefter valdes en hopskriven form, Iberoamerikanska institutet. 
och kunskaper om områdenas kultur och historia ansågs viktiga, senare uttryckt av professorn i Romanska språk Karl Michaëlsson (1890-1961) som att "språkläraren är dock humanist" och språkundervisningen skulle

skapa en produkt, varav vårt land har ett än mer trängande behov: människor, som inte blott kunna räkna, utan också tänka själva, produkten av generationers tankeid, ej blott i vårt land utan också hos andra folk. (1956: 71-72)

Spanska ersatte ryska höstterminen 1928 och ledningen såg införandet som en stor succé. ${ }^{33}$ I en sammanställning över vilka ämnen som ingått i examina 1924-1933, kan vi se att 13 studenter examinerats i långa kursen och 15 i korta kursen, medan franskan, som funnits med från början, hade 16 studenter i långa kursen och $8 \mathrm{i}$ den korta. Flest examina hade engelska och tyska. När det gällde de s.k. handelshögskolekurserna (offentliga kvällsföreläsningar) delade spanskan första platsen med engelskan under samma period med 316 deltagare (Berglund 1933).

Modernisering och breddande av undervisningen var något som Hedberg hade gemensamt med Goulard och Lundgren. På Handelshögskolan syns spänningen mellan språkfärdighet och språkvetenskap i kurserna, framför allt i form av språkhistoria, såsom Lindberg och Nilsson beskriver den på Högskolan, närmast obefintlig (1996: 139 ff.). ${ }^{34}$ Från läsåret 1937-38 framgår att Hedberg berikat innehållet genom att införa realia, dittills hade spanskan innehållit grammatik, översättning, konversation, handelskorrespondens och litteraturstudier. Inför revideringen av Handelshögskolans Studiehandbok (1942) utökades den latinamerikanska delen av litteraturhänvisningarna. Läsåret 1941-1942 innehöll de kurser som var öppna såväl för handelshögskolestudenterna som för allmänheten, 30 föreläsningar över latinamerikanska förhållanden. Ett av flera syften med inrättandet av Iberoamerikanska institutet var att åstadkomma den här förändringen med mer fokus på Latinamerika och med införande av mer samtida litteratur genom att skapa ett specialbibliotek för den spansk- och portugisisktalande

33 Ryska återkom höstterminen1936 med Hedberg som lärare, och han hade även en propedeutisk kurs i ryska på högskolan 1941/42-1942/43.

34 Riksföreningen för lärarna i moderna språk var aktiva för en modernisering av universitetens kursinnehåll och en minskning av det språkhistoriska innehållet, vilket kan följas i deras skrivelser i samband med de olika utbildningsutredningar som pågick under 1940-talet. Kopior finns publicerade i föreningens årsskrift, exempelvis för åren 1945, 1946 och 1947 (1946-1948). 
världen (PM återgivet i Handelshögskolan i Göteborg Årsberättelse 1939: 85-87).

En bakgrund till Goulards intresse för att modernisera undervisningen hittar vi i hennes egen utbildning. Hon kom från en liberal familj och före Facultad de Filosofía y Letras gick hon i den progressiva skolan Institución Libre de Enseñanza; Ellen Key var ett välkänt namn i hemmet. Hennes läromedel Siete hermanos (Goulard 1953) är särskilt intressant att nämna, ambitionen var att presentera modern och ungdomlig spanska. Formen för detta blev att använda sig av systern Elena och hennes sju barn och genom att skildra deras vardag hitta ett naturligt sammanhang för det språk Goulard ville föra fram och samtidigt beskriva spansk samtid. Att hon i den här typen av läromedel för språkfärdighet inte såg någon motsättning i att språkstudier även måste inkludera studier i litteratur, uttrycker hon tydligt för universitetsnivån i en artikel från 1954 om spanskans ställning i Sverige; själv tillämpade hon detta även för skolradion där hon använde Juan Ramón Jiménez poesi (Goulard 1954; 1983).

Bland hennes andra aktiviteter utanför arbetet på Handelshögskolan och GU finns Folkuniversitet i Stockholms Spanska veckan, en återkommande sommarkurs där hon 1944-1947 undervisade tillsammans med Max Gorosch och Ernesto Dethorey (1901-1992). Hon läste in grammofonskivor för NKI-skolans spanskkurs och tillsammans med Gorosch skrev hon Spansk grammatik 1949 som kom ut i flera upplagor. 1952 examinerade hon den första gruppen studenter som hade spanska i studentexamen. Under många år var hon vice ordförande i Asociación Europea de Profesores de Español, den europeiska organisationen för spansklärare.

Iberoamerikanska institutet var också en viktig miljö för första ordinarie universitetslektorn i spanska på GU Börje Cederholm, som fick tjänsten 1968 efter att ha varit lärare och e.o. lektor sedan 1960 och verksam på Handelshögskolan under slutet av 1950-talet. Cederholm blev fil.lic. 1949 med ett arbete om Mariano Azuela, vars roman Rebellerna han senare översatte med Karin Alin (1892-1974). ${ }^{35}$ Trots sin litterära lic.-avhandling

35 Cederholm var på ett stipendium i Mexiko under slutet av 1940-talet och undervisade då vid Universidad Nacional Autónoma de México höstterminen 1948 och vårterminen 1949 på en svenskkurs tillsammans med pressattachén Börje Söderlund (1918-1990) (Söderlund, 1949). De gjorde ett studiematerial Introducción al estudio del idioma sueco 1949. Det utvecklades till en bok 1952, Doce lecciones de sueco, som kom ut i flera upplagor. 
blev det lexikologi med särskild inriktning på amerikansk spanska som blev Cederholms huvudsyssla. Svensk-spanskt lexikon som han gav ut 1961 ihop med lektorn i franska och läraren i spanska vid Göteborgs handelsinstitut fil. lic. Nils Sund (f 1898) var efterlängtat och länge det mest omfattande som fanns att tillgå (Heurlin 1961). ${ }^{36}$ Cederholm samarbetade med Jaime Peralta (1924-1983) i Svensk-spansk affärsordlista utgiven 1964. Såväl lexikonet som ordlistan utgavs i samarbete med Iberoamerikanska institutet. Peralta som var chilenare kom till institutet som stipendiat 1961, under åren1962 till 1967 anlitades han även som lärare och utländsk lektor vid GU. Det spansk-svenska lexikon som Cederholm också arbetade med fick han aldrig se i tryck. Fyra år efter hans död kom Spansk-svensk ordbok till slut ut 1976 med hjälp av ett flertal medarbetare, bland dem mexikanen Joel Rangel Gallardo (f 1938), ännu en av institutets stipendiater från 1961, som kom att stanna kvar i Sverige och på institutet.

\subsection{Arne Lundgren}

\subsubsection{Vägen till de romanska språken}

Om Hedberg gick från en gängse akademisk karriär mot diplomatliv och institutionsbyggande och Goulard mot praktisk utveckling av språkundervisningen inom och utanför akademin, så kom Arne Lundgren att uppvisa en i ännu högre utsträckning diversifierad karriär som romanist: handelskorrespondent, lärare, översättare, introduktör, lektör, kritiker, förläggare. I den självbiografiska texten ”En bakgrund, rekonstruerad” (1967) och i korrespondensen, särskilt den djupt personliga med Per G. Ekström (1908-1998), först hans lärare i portugisiska och senare vän, tonar bilden fram av en ambivalent student och akademiker. Vägen från den bohuslänska födelseorten Hovenäset till universitetet krävde uppoffringar och hårt arbete. Redan från 14 års ålder blev han en mångsysslare för att finansiera studierna först på Östra Real i Göteborg och senare på Hvitfeldtska högre allmänna läroverket. Han hade lätt för sig, särskilt i språken, men han var också frustrerad över innehållet i undervisningen, fokuseringen på det his-

36 Sund var även medförfattare till Lärobok i spanska från 1939 ihop med Erland Högdahl (1899_ 1949), affärsman och göteborgsk vicekonsul för Spanien som skrev läroböcker i italiensk och spansk handelskorrespondens, och med Aurelio Viñas (1892-1958), spansk historiker verksam vid Institut d'Études Hispaniques vid Sorbonne och författare till läroböcker i spanska för fransk publik (Prekel 2015). 
toriska. En lärare på Hvitfeldtska han dock beundrade var lektorn i engelska och franska Ernst Bendz (1880-1966) som sysslade med modern litteratur och som fick Lundgren att bli mer intresserad av franska och att vilja bli "en lika suverän översättare" som denne (Lundgren 1967: 128). ${ }^{37}$ Under gymnasietiden läste han spanska på kvällskurser. Ett viktigt incitament för språkstudierna var också det omvärldsintresse som vaknade i samband med spanska inbördeskriget (Lundgren 2001).

Efter studentexamen 1946 och lumpen, då han för övrigt läste en Hermodskurs i italienska, började han 1947 på fackkursen vid Göteborgs handelsinstitut. Det som egentligen hägrade var språkstudier vid Göteborgs högskola, men av ekonomiska skäl blev det istället en kortare praktisk utbildning, dock läste han portugisiska på Handelshögskolans kvällskurser. Men ett år senare, samtidigt som han började jobba som handelskorrespondent på Elof Hansson, skrev han in sig i Romanska språk på Högskolan med en fil.mag. som tänkt slutmål; det skulle ta tolv år innan den examen var i hamn. Han hann gifta sig, få barn och arbeta på Beijers innan han definitivt lade karriären som handelskorrespondent på hyllan 1954, och efter att ett år ha arbetat i en väns firma bestämde han sig för att ägna sig åt studier och skrivande på heltid. Under den här perioden kämpade han på med studierna, "cyklade under lunchen på en timmas föreläsning till Högskolan" (Lundgren 1967: 133), blev lärare i portugisiska på Handelshögskolan, undervisade i spanska på $\mathrm{ABF}$, blev translator publicus i portugisiska, hjälpte Goulard med radiokursen Siete hermanos, kom ut med sina första skönlitterära verk och de första översättningarna publicerades.

\subsubsection{Portugisiska och mötet med Per G. Ekström}

Som översättare skulle Lundgren komma att tolka från fem romanska språk. Summerar vi bibliografin i Svenskt översättarlexikon (u.å.) och lägger till en del tidnings- och tidskriftspubliceringar som saknas där, hann Lundgren med att publicera 5 författare från franska, 7 från italienska, 11 från katalanska, 85 från spanska och 114 från portugisiska. ${ }^{38}$ I olika sammanhang gav

37 Ernst Bendz disputerade i Lund 1914 med en avhandling om Oscar Wilde, skrev introducerande artiklar om fransk litteratur i göteborgsspressen och i bokform. I GUB finns brev till Bendz från bland andra Louis-Ferdinand Céline, Georges Duhamel André Gide, Panaït Istrati, Albert Paraz och Paul Valéry. Arkivförteckning finns: Göteborgs universitetsbibliotek H 126 http://urn. kb.se/resolve?urn=urn:nbn:se:alvin:portal:record-114382. 
han uttryck för att han tidigt såg den spanskspråkiga och i högre grad den portugisiskspråkiga litteraturen som förbisedd i Sverige (se t.ex. Lauritzen 1988; Lundgren 2001). Men det var inte bara en fråga om underrepresentation. I ett brev till FIB:s Lyrikklubb skrev han att den portugisiskspråkiga poesin fascinerat honom mest av de romanska språkens och att den passade lika bra för lyrik som italienskan. Han fortsatte: "Den brasilianska poesin tilltalar mig alldeles speciellt genom sin fusion av intellekt och känsla och genom sina exotiska inslag, den är nyanserad och ganska enastående, tycker jag." (Lundgren 1955c).

Lundgrens först utgivna översättning blev en antologi 1951 av den brasilianske författaren Ribeiro Couto som han översatte tillsammans med Ekström, som då redan hade publicerat några översatta dikter och en stor översiktsartikel om brasiliansk poesi i Göteborgs Handels- och Sjöfartstidning (1947). I förordet till antologin Fem brasilianska poeter från 1961 ger Lundgren en stämningsbild från sin väg in i den brasilianska litteraturen.

Min första bekantskap med brasiliansk lyrik gjorde jag i ett litet annex vid Arkitektgatan i Göteborg. Bland saxande boktravar på bord, golv och stolar i ett litet rum, där gnisslet från spårvagnar och skenet från en bensinmack slog in genom de låga fönstren, förmedlade Per Ekström, son till den öländske solmålaren med samma namn, den första stimulerande kontakten. Vid sin flyttning till Öland för tio år sedan lämnade han mig tolkningar och utkast till tolkningar, som jag i flera fall utgått från eller omarbetat. Jag är honom mycken tack skyldig. (Lundgren 1961: 9)

Annexet var en del av Handelshögskolans dåvarande lokaler och där huserade Iberoamerikanska institutet tills lokalerna på Vasagatan stod klara 1952. Kursen i portugisiska infördes av Hedberg 1945, bekostades till en början av Elof Hansson och hade sju elever under sin första termin. Handelshögskolan var nöjd och beslöt att inför kommande läsår införa ämnet som tentamensämne som en kortkurs, likställd med de kurser man hittills haft i ryska.

När Per G. Ekström anställdes som lärare studerade han sedan 1942 i Göteborg där han hamnat tack vare Gunnar Ahlborn, som han hade träffat i Paris när denne var lektor i svenska vid Sorbonne. Bakom sig hade han

inte det som man i Lundgrens korrespondens ser har sänts. För översättningar till svenska från Portugal före Lundgren se Gyberg (1975). 
en kringflackande ungdom med studier i Lissabon och Sorbonne där han utöver franska ägnade sig åt portugisiska och brasilianska studier. Han skrev en licentiatavhandling i franska 1948, undervisade på Samskolan och Hvitfeldtska och disputerade sedan 1953 med en avhandling om Pierre Loti, men trivdes inte i Göteborg och med det akademiska livet; han var också anfrätt av religiösa grubblerier och hälsoproblem inom familjen. I memoarboken Uppgörelser kallar han Lundgren för sin duktigaste elev (Ekström 1985). När han avvecklade sitt liv i Göteborg, fick Lundgren ta över undervisningen, först som vikarierande läsåret 1951/52 och sedan som ordinarie 1953 och fram till språkets sista läsår 1969/70. Det dröjde dock till 1960 innan han fick examinera, Ekström fortsatte ett tag och sedan tog Hedberg över. I årsberättelserna från senare halvan av 1950-talet står uttryckligen att undervisningen koncentrerades på brasiliansk portugisiska. Vad årsberättelserna inte visar är att undervisningssituationen inte alltid var så lätt. I ett brev till Ekström skriver Lundgren om heterogena grupper med portugisiskor som egentligen ville lära sig svenska och SKF:are på väg till Brasilien. Hans egna intressen, som egentligen var helt inriktade på litteraturen, fick honom att tvivla på om han förmådde fängsla studenterna tillräckligt för att de skulle uppnå den språkfärdighet de var ute efter (Lundgren 1963).

\subsubsection{En akademisk karriär?}

Liksom i Uppgörelser ger brevväxlingen mellan Ekström och Lundgren en bild av gemensamma erfarenheter, att försöka göra en akademisk karriär och samtidigt försörja sig och sin familj, en delad känsla av att inte passa in i den akademiska miljön, men också uppskattning för Karl Michaëlsson som en akademiker med stor förståelse för sina adepters olika tillkortakommanden. Under sin professorstid fick han igenom 13 doktorsavhandlingar, mer än dubbelt så många som efterträdaren Hans Nilsson-Ehle (1910-1983). I memoarboken skriver Ekström:

Så kom disputationen. Min vän, andre opponenten, Monsieur Pougnard, meddelade i förtroende vad förste opponenten Sørensen ämnade kritisera. [...] Min lärare Karl Michaëlsson myste. Jag var glad för hans skull, att jag kommit så långt. Jag kände en stark tillgivenhet för honom. Han hade förstått min trötthet, mitt mindervärdeskomplex. (Ekström 1985: 71) 
Han uppmanade Lundgren att se till att bli klar med sin examen medan Michaëlsson var kvar, "han är förstående och överseende, han ser till det väsentliga, till intresset, uppriktigheten" (Ekström 1954). Lundgren hade dock ett vidare problem än Ekström, tidens regler tycktes sätta käppar i hjulet för vad han egentligen skulle velat ägna sig åt inom det akademiska. Skulle det vara möjligt att skriva en doktorsavhandling på portugisiska om havet som motiv i luso-brasiliansk lyrik? Eller det kanske skulle vara säkrare att satsa på något jämförande romanskt i portugisisk lingvistik och skriva på franska? (Lundgren 1955a). Skulle man kunna skriva en uppsats i franska om Georges Bernanos tid i Brasilien för att bereda marken för en lic.-avhandlingen om Jorge de Lima? (Lundgren 1955b). Den senare hade han fastnat för under översättningar av brasiliansk lyrik, de korresponderade och Lundgren funderade över om det skulle gå att lissa på en avhandling om Lima. Italienska, portugisiska och spanska tentades av men franskan tog tid. Ekström läste uppsatsen om Bernanos som Michaëlsson tyckte att det lades för mycket krut på, professorn ville se Lundgren klar (Lundgren 1955d). Betygen blev många men de gick inte att kombinera till en examen. Han kallade universitetets miljö för "halv-fnoskig" och "skit-intellektuell" när han kämpade med någon pedagogisk tentamen (Lundgren 1957b).

Efter att ha vunnit Wahlström \& Widstrands romanpristävling med Man överbord 1958 skrev han till Carl Björkman att priset givit honom andrum att kunna slutföra studierna men att när "studiefrågan är ur världen har jag förmodligen dock oåterkalleligen hemfallit åt litteraturen", detta även om han troligtvis måste fortsätta med översättningar för att "existera drägligt" (Lundgren 1958). Trots allt, efter fil. magexamen 1960 fortsatte han som lärare i portugisiska på Handelshögskolan och arbetade 1968-1979 som tf. lektor i realia och spansk-amerikansk litteratur på GU, som omöjligen skulle kunnat få tag på samma kompetens inom de disputerades led. En kompetens som var ett resultat av Lundgrens gärning som översättare och introduktör och som inte bara krävde tid och möda utan, trots tillgång till institutets bibliotek, en stor ekonomisk insats med bokinköp och prenumerationer från utlandet. ${ }^{39}$

39 Det finns en hel del beställningar och kvitton i arkivet. Av vissa kan vi utläsa vad han avsåg att läsa med studenterna, exempelvis ht. 1970: García Márquez Cien años de soledad, Onettis El astillero och Barnets Biografía de un cimarrón (Lundgren 1970b). 


\subsection{4 Översättandet tar fart}

Efter att Ekström återvänt till Öland fortlöpte under 1950-talet planer på en antologi över modern brasiliansk lyrik, helst en tvåspråkig. Lundgren var nu den drivande och i brevväxlingen funderade han kring hur de skulle tänka kring urvalet, brasiliansk kanon eller enskilda dikters eget värde? (Lundgren 1955a). Passa på att fråga författarna om vilka dikter de själva tycker är representativa när man ändå kontaktar dem om tillstånd för översättning? (Lundgren 1953). I nr 2 av göteborgska kulturtidskriften Paravan fick de 1952 in några av de poeter de höll på med, Carlos Drummond de Andrade och Ronald de Carvalho samt Manuel Bandeira i nr 6 1954. Året före lyckades Lundgren få med ett femtontal översättningar av tio diktare i radioprogrammet Nattövning. Uppläsningarna i radion är intressanta då flera av dikterna kom med där innan översättningarna publicerats i tryck och i arkivet finns mycket korrespondens mellan Lundgren och Radiotjänst/Sveriges Radio. Han skickade ofta in förslag och gjorde också egna program eller fick texter framförda. Uppenbarligen var mediet en betydande kanal för avsättning av översättningar och introduktioner av författarskap. Carlos Drummond de Andrade blev Lundgrens mest översatte författare med sex monografier och flera bidrag i antologier och tidskrifter; i arkivet finns korrespondens och de träffades också. Andrade skrev en artikel om Lundgren i dagstidningarna Correio da Manhã och O Diario som höjde honom till skyarna, och skrev dessutom ut hans hemadress och institutets och uppmanade författarkollegor att skicka sina verk till denne tillskyndare av den brasilianska litteraturen (Andrade 1957).

I slutet av artikeln nämner Andrade att Artur Lundkvist besökt honom och att denne håller på att ge ut antologin Den mörke brodern. Lundgren blev inblandad i antologin med "negerlyrik" 40 genom att FIB Lyrikklubbs redaktör Stig Carlsson (1920-1971) skickade några av hans brasilianska tolkningar vidare till Lundkvist (Carlson 1955). Från början var det tänkt att den även skulle innehålla nordamerikanska poeter (Lundkvist 1955), men de valdes bort när fler spansk- och franskspråkiga tillkom. Lundgren och Lundkvist träffades i Göteborg hösten 1955 och uppe i Bohuslän

40 Negerbegreppet i antologin diskuteras i Alvstad \& Lundahl (2011); som komplement till deras diskussion om vilka antologier som kunde ligga till grund för urvalet, framgår av korrespondensen att Lundgren hade tillgång till Lira negra: selecciones españolas y afroamericanas utgiven i Madrid 1945 och Antologia di poeti negri utgiven i Florens 1954. 
sommaren 1956, men annars fick det mesta av arbetet skötas per brev och telefon; Lundgren tog fram flera av de texter som Lundkvist inte lyckats får tag på. Jorge de Lima är den enda brasilianaren som kom med i antologin, men Lundgren översatte även några av de spansk- och franskspråkiga författarna. Lasse Söderberg (f 1931) deltog med tolkning av Aimé Césaire och Édouard Glissant. Lundgren granskade allas översättningar och tycks haft många synpunkter på dem. Några av dikterna hade han dock inte fått tag på i original, men Lundkvist tyckte att de inte behövde granskas vidare. Lundgren ansåg det nödvändigt och bad Carlson att diskret ta upp det med Lundkvist (Lundgren 1956c). Ernesto Dethorey gjorde en sista granskning av de spanska översättningarna, Lundgren var mycket tacksam men påpekade också att han framför allt av rytmiska skäl valt en friare svenska, det var svårt "att göra dessa 'exotiska' poeter full rättvisa" (Lundgren 1957a). Särskilt Lima, Glissant och Césaire såg han som svåröversatta och tyckte att särskilt den senare fick för stort utrymme, hans "paroxysmer" blir på svenska "i bästa fall ett svagt eko" (Lundgren 1956b). När boken väl utkom 1957 skrev Stig Carlson (1957) att projektet nog aldrig hade kommit i mål om inte Lundgren lagt ner så mycket arbete, inklusive läsning av allas korrektur, framtagande av bilder på och adresser till författarna. Lundkvist gjorde sitt jobb och skyndade vidare till något nytt, detaljerna fick någon annan ta hand om.

Samtidigt som arbetet med Den mörke brodern pågick föreslog Lundgren (1955e) att FIB skulle satsa på något italienskt, Eugenio Montale eller Cesare Pavese, i vilken han fann en rotlöshet som han kände sig besläktad med och även en motivkrets, sandgrävarna, som han jämförde med sin egen från sillsalterier. Men bäst tyckte han om Salvatore Quasimodo som han träffade i Italien 1955, då hade de första tolkningarna redan publicerats i Paravan 1954. Från första manuskript till den färdiga boken 1957 skedde en hel del revideringar, bland det sista lades urval till från Ed è subito sera som Lundgren föreslår som tolkningsvolymens titel, Och plötsligt är det afton. Han rådfrågade Quasimodo om tolkningar och italienska lektorn Adamaria Terziani (f 1921) ${ }^{41}$ granskade, liksom Bengt Holmqvist (Lundgren

41 Terziani var lektor i italienska vid GU från ht 1950, först som vikarierande och ordinarie ht 1953-vt 1960. Hon publicerade en italiensk läsebok Mille parole 1950 ihop med översättaren Ebba Atterbom (1868-1961), gjorde en italienskkurs i radion 1951, Un viággio in Italia, och översatte också en del svensk litteratur, bland annat Selma Lagerlöfs Kejsaren av Portugalien. 
1956a). Trots det han uttryckte om portugisiskans företräden i Bohuslän $i$ svartvitt menade Lundgren att italienska var det språk han blev bäst i och att det var det vackraste av de romanska språken (Lundgren 2001). Liknande tankegångar finns i brev till Terziani, att han alltid tyckt bäst om italienska språket; han beklagade att översättningar av bland andra Montale blivit liggande hos FIB:s Lyrikklubb och blivit inaktuella då andras hunnit före (Lundgren 1964). Utöver Quasimodo publicerade Lundgren i bokform översättningar av Sergio Talenti, Giuseppe Bonaviri och Pier Paolo Pasolini.

Efter Quasimodo och Den mörke brodern började ett samarbete med Norstedts, som gav ut romandebuten Bottnens klockor 1957, ett urval spansk-arabisk poesi Rosor på floden 1958 och Syster Marianas kärleksbrev 1959. Därefter följde några antologier där mer än ett decenniums arbete fick sitt utlopp. Portugisiska berättare 1960 med översättningar även av Sven Bjellerup och bibliotekarien vid Göteborgs universitetsbibliotek Erik Gyberg (1923-1989), Fem brasilianska poeter 1961 samt, i översättarsällskap med göteborgstrion Per Rosengren, Erik Gyberg och Erik Michaëlsson (1926-1999) ${ }^{42}$, Latinamerikanska berättare 1963, det dittills mest omfattande urvalet av prosaister från Latinamerika på svenska. Han skrev i ett brev långt senare att han avverkade hyllmetrar av litteratur för urvalet och nämnde att av alla arbeten var sammanställandet av antologier det mest krävande; han var ytterst noggrann med urvalet inte enbart utifrån de enskilda författarskapen utan för att antologin som sådan skulle hålla linje och balans (Lundgren 1994). Dessutom stod han själv för alla kontakter med författarna eller deras efterlevande för att skaffa tillstånd för översättningarna. Alla var inte lätta att få kontakt med, ibland fick han be dem som svarade om hjälp med att kontakta någon kollega. Somliga var särskilt tacksamma över uppmärksamheten, som Lygia Fagundes Telles som skrev att språket utgjorde en svår barriär för de brasilianska författarna, men när de väl kunde passera den gav det hopp om att en gång få en publik utanför Brasilien och Portugal; hon var också imponerad av Lundgrens portugisiska (Telles 1963). Flera av författarna som är med i Latinamerikanska berättare kände Nils Hedberg så Lundgren hänvisade till honom när han kunde.

42 Erik Michaëlsson, fil.lic. 1958 med en avhandling om fransk litteratur, arbetade som lärare vid Högskolan i både franska och italienska och översatte Cesare Paveses Månen och eldarna 1954. 
Att Lundgren själv inte översatte alla bidrag i antologierna var inte bara en fråga om arbetstid utan ett medvetet val att få många svenska hispanister eller lusofiler att medverka (Lundgren 1959b).

\subsubsection{Att fortsätta kämpa och att gå sin egen väg}

En av Lundgrens kontakter som skrev artiklar om honom och om svensk litteratur var portugisen Silva Duarte (1918-2011), sedermera verksam vid universitetet i Frankfurt. Han lärde sig svenska och danska på egen hand och översatte till portugisiska, bland andra Artur Lundkvist och Harry Martinson. Lundgren lärde känna honom i Portugal 1955 och bistod ibland vid översättningsproblem (Lundgren 1959a). De utbytte tips om texter att översätta och i brevväxlingen kan skönjas gemensamma erfarenheter såsom förlagens relativa ointresse för det andra landets litteratur. Även Nils Hedberg hade täta kontakter med Silva Duarte och Iberoamerikanska institutet bidrog till utgivandet av Cinco poetas suecos 1966 och 1981. Vid besök på institutet 1963 höll Duarte ett föredrag om Fernando Pessoa, en författare Lundgren under flera år försökte få svenska förlag att intressera sig för; av rättighetsinnehavarna hade han fått tillstånd att publicera utan ersättning. På 1950-talet skickade han in några översättningar till tidskrifter som t.ex. Upptakt där Tomas Tranströmer utöver brist på utrymmer tyckte att diktaren, som han fann intressant, borde sparas till ett portugisiskt tema om tidskriften överlevde (Tranströmer 1957). På 1960-talet bekymrade sig Lasse Bergström å Norstedts vägnar först för att man inte kunde ge ut både en bok av Lundgren själv samt en med hans översättningar av Pessoa under samma år, och därefter för att manuset var alltför omfattande och inte kunde göra portugisen rättvisa då boken skulle bli alltför dyr (Bergström 1968a; 1968b). Även Lars Gustafsson på Bonniers tyckte att boken var för omfångsrik, men också att Pessoa inte var tillräckligt gammal för att anses som en klassiker och inte heller tillräckligt ny för att inspirera den samtida svenska lyriken (Gustafsson 1970). Det hjälpte inte att minska omfånget och till slut gav Lundgren ut Fernando Pessoa: ett diktaröde 1973 på Ny litteratur Futura, ett förlag startat av översättarkollegan Alexander Fernandes (f 1929), och Stilla, mitt hjärta på egna Fabian 1988. På förstnämnda förlag kom också angolanen Castro Soromenhos Död jord ut 1976, inom Lundgrens radar på 1950-talet och refuserad av flera. 
Bakom refuseringar låg förstås ekonomiska kalkyler. Några exempel ur korrespondensen ger en bild av hur förlagen i övrigt motiverade sina avslag såväl av Lundgrens egna översättningar som av hans andra förslag. Trots att det fanns en insikt om att man var bristfällig vad gäller spansk- och portugisiskspråkig litteratur kom få till skott. Gunnar Harding på FIB:s Lyrikklubb refuserade ett nytt urval Andrade med argumenten att de redan var på väg att ge ut en latinamerikansk poet, Cesar Vallejo ${ }^{43}$, samt att Lundgren ju redan introducerat Andrade i bokform (Harding 1972). Lasse Bergström refuserade en andra bok av Aquilino Ribeiro med argumentet att Norstedts gjort sin "introduktionsplikt" och Guimarães Rosas Livet är farligt, senhor ansåg han för svåröversatt och det som skiljde den från europeisk romankonst, "myllrande", "svåröverskådlig" blir till bokens nackdel (Bergström 1970; 1963). I en enkät i Böckernas värld ställdes frågan vad som var utslagsgivande för att en roman skulle översättas. Lundgren svarade att den "är 'sensationellt' bra" och att författaren är ung eller en "potentiell Nobelpristagare". Avgörande faktorer för att den inte blev översatt var "att den är tekniskt eller konstnärligt avancerad, att författaren är död, att boken är för tjock" (Gummerus 1968: 50). Även med tidskrifter var det en kamp och texter kunde bli liggande i åratal. Efter fyra år av väntan på svar om en text av Urbano Tavares Rodrigues, konstaterade Lundgren att det är "ungefär lika svårt att komma till tals med BLM som med en svensk bostadsförmedling" (Lundgren 1968a).

Utöver sina egna översättningar arbetade Lundgren med att i hundratals artiklar i dagspress och tidskrifter introducera författarskap och recensera, framför allt i Göteborgs Handels- och Sjöfartstidning och Göteborgs-Posten. Arkivet innehåller många brev till förlag med förslag på böcker de borde skaffa option på, bland exemplen finns Elena Poniatowskas La noche de Tlatelolco till Forum 1972, García Márquez Cien años de soledad och Octavio Paz El laberinto de la soledad till Norstedts 1968 respektive 1960. I brev från 1950-talet tipsades om Juan Goytisolo, Ana María Matute, Elena Quiroga, Miguel Delibes och Rafael Sánchez Ferlosio. De här förslagen var inte nödvändigtvis potentiella egna översättningar. Sverker Göransson (u.å.) skriver i Svenskt översättarlexikon att Lundgren själv valde vad han ville översätta

43 En översättning som Lundgren förövrigt granskade i korrektur och hade många kritiska synpunkter på (Lundgren 1970a). 
och sällan gjorde beställningsjobb, arkivet bär spår av detta. Bland dem han tackade nej till finns från förlaget Nordan Juan Carlos Onettis Los adioses (Ta farväl) som han inte gillade utan tyckte att de borde ge ut El astillero eller Juntacadáveres istället; inte heller Aura av Carlos Fuentes intresserade honom tillräckligt (Lundgren 1981a; 1981b). För Nordan gav han dock ut en tvåspråkig utgåva av Andrade och var med i Clarice Lispectors Familjeband till vilken han skrev förordet och översatte novellen "Hönan".

På 1980-talet startade Lundgren förlaget Fabian, trött på att kämpa för att få gehör för sina texter hos förlagen. Men en kamp var det fortsatt ändå. När han arbetade med sitt översiktsverk om portugisisk 1900-talslitteratur Oceanernas oro, bergens tystnad skrev han i ett brev till portugisiska Fundação Calouste Gulbenkian att han köpt böcker från Portugal för 11500 kronor för arbetet, samtidigt som svenska bibliotek endast köpt 37 exemplar av nyss utgivna Aquilino Ribeiros Doft av ginst och vadmal (Lundgren1996).

I valet av verk han översatte lyser ofta ett socialt och politiskt engagemang igenom. Under de första decennierna han var verksam var det inte bara ett flertal latinamerikanska länder som var diktaturer utan såväl Spanien som Portugal. I ett brev till Carl Magnus von Seth i samband med att Sveriges Radio antagit novellen "Allt ska bli annorlunda" av Maria Judite de Carvalho skriver Lundgren att förlagens ointresse för de portugisiska författarna är "genant", särskilt som dessa "känner att de lever i en monolog och att de behöver känna att omvärlden vet att de finns till” (Lundgren 1968b). När Bonniers givit ut svenska dramatikantologin Refuserat 1969, förslog han dem förgäves att under titeln "Förbjudet" ge ut Dias Gomes från Brasilien, Lauro Olmo från Spanien samt Augusto Abelaira och Luis Sttau Monteiro från Portugal, den senare bifogar han färdigöversatt (Lundgren 1969a). Han undervisade ju även i realia vid GU och höll sig à jour med vad som hände i de länder vars litteratur han intresserade sig för, och under en period på 1970-talet ansvarade han för en spalt, "Det händer i Latinamerika”, i Göteborgs-Posten. Prenumerationer på ett tiotal latinamerikanska tidskrifter gjorde honom "hyggligt insatt i vad som hände på den stora kontinenten" (Lindkvist 2000).

I arkivet finns också brev från personer som bad om råd av allehanda slag. Som avslutning får Lundgrens svar på ett av dessa sammanfatta några av de egenskaper, utöver den litterära talangen, som lyser igenom i breven: 
omsorg om språket, engagemang, allvar och humor. Bo Setterlind bad inför en resa om förslag på en plats i Latinamerika som en poet inte borde missa. Arne Lundgren svarar:

En plats en poet inte bör missa? Det skulle i så fall vara storstadens slum - 'villas miseria' i Buenos Aires, 'callampas' i Santiago de Chile, 'barriadas' i Lima, 'tugurios' i Bogotá, 'los ranchitos' i Caracas, 'mocambos i Recife', 'favelas' i Rio, med andra ord ett elände och ett problem som är allmänt och, jag börjar nästa tro, olösligt, med den inställning som nu råder på de flesta håll. (1969b)

\section{Bibliografi}

Alvstad, Cecilia, \& Lundahl, Mikela, 2011: Den mörke brodern: Svensk negrifiering av svart poesi 1957. Tidskrift för litteraturvetenskap, 40(2). 39-53.

Andrade, Carlos Drummond de, 1957: Lundgren, Ludkvist [sic]. O Diario, $17 / 11$.

Baeckström, Lorica, 1966: Spanjorska på svensk chefsstol. Göteborgs Handels- och Sjöfartstidning, 12/11.

Bernabéu Albert, Salvador, 2005: La pasión de Ramón Iglesia Parga (19051948). Revista de Indias 65(235). 755-772.

Berglund, Hadar, 1933: Handelshögskolan i Göteborg: tioårsöversikt 1923-1933. Göteborg: Elanders.

Berglund, Hadar, \& Grönfors, Kurt, red. 1977: Handelshögskolan i Göteborg 1923-1971: en minnesbok. Göteborg: Västsvenska akademibokhandeln.

Bergström, Lasse, 1963: Brev till Arne Lundgren 28/10. Författaren Arne Lundgrens papper, H 2011:12. Göteborg: Göteborgs universitetsbibliotek.

Bergström, Lasse, 1968a: Brev till Arne Lundgren 24/1. Ibid.

Bergström, Lasse, 1968b: Brev till Arne Lundgren 17/12. Ibid.

Bergström, Lasse, 1970: Brev till Arne Lundgren 14/1. Ibid.

Carlson, Stig, 1955: Brev till Arne Lundgren 6/8. Ibid.

Carlson, Stig, 1957: Brev till Arne Lundgren 4/9. Ibid.

Ekström, Per G., 1947: Brasiliansk poesi. Göteborgs Handels- och Sjöfartstidning 12 november.

Ekström, Per G., 1954: Brev till Arne Lundgren 2/2. Författaren Arne Lundgrens papper, H 2011:12. Göteborg: Göteborgs universitetsbibliotek.

Ekström, Per G., 1985: Uppgörelser. Kalmar: P.G. Ekström.

Gorosch, Max, 1953: Spanskan vid universiteten och högskolorna. Riksföreningen för lärarna i moderna språk 1952. Bromma: Riksföreningen. 37-42. 
Goulard, Matilde, 1953: Siete hermanos: spansk språkkurs i radio hösten 1953. Stockholm: Radiotjänst.

Goulard, Matilde, 1954: La lengua española en Suecia. Boletín de Información: Cámara de Comerico de Suecia en España 3. 15-17.

Goulard, Matilde, 1969-1971: Nils Hedberg. Svenskt biografiskt lexikon 18. 391.

Goulard, Matilde, 1983: Utilización de Juan Ramón Jiménez en la escuela. Boletín de la Asociación Europea de Profesores de Español 28. 69-74.

Gummerus, Teddy, 1968: Det där med översättningar: tio frågor från en bokkonsument. Böckernas värld 5. 48-51.

Gustafsson, Lars, 1970: Brev till Arne Lundgren 30/4. Författaren Arne Lundgrens papper, H 2011:12. Göteborg: Göteborgs universitetsbibliotek

Gyberg, Erik. 1975: Portugal i svensk litteratur: en bibliografi. Göteborg: Göteborgs universitetsbibliotek.

Göransson, Sverker, u.å.: Arne Lundgren. Svenskt översättarlexikon. http://www. oversattarlexikon.se/artiklar/Arne_Lundgren. [2017-08-04]

Göransson, Sverker \& Lindvall, Lars: 1990: [Förslag och motivering för Arne Lundgren som hedersdoktor]. Göteborgs universitet, B9a:20. Göteborg: Landsarkivet.

Göteborgs högskola, 1891-1954: Göteborgs högskolas katalog. Göteborg: Göteborgs högskola.

Göteborgs högskola, 1892-1956: Årsredogörelse. Göteborg: Göteborgs högskola.

Göteborgs universitet, 1954-1960: Göteborgs universitets katalog. Göteborg: Göteborgs universitets studentkår.

Göteborgs universitet, 1960-1964: Göteborgs universitets katalog: lärare, undervisning och examination: administrativa uppgifter. Göteborg: Göteborgs universitet.

Göteborgs universitet, 1965-1974: Göteborgs universitet: administrativa uppgifter: lärare. Göteborg: Göteborgs universitet.

Göteborgs universitets studentkår, 1960: Katalog, Höstterminen 1960. Göteborg: Göteborgs universitets studentkår.

Hallberg, Severin, 1942: Göteborgs högskolas matrikel 1916-1941. Göteborg: Göteborgs högskola.

Handelshögskolan i Göteborg, 1923-1960: Årsberättelse. Göteborg: Handelshögskolan.

Handelshögskolan i Göteborg, 1942: Studiehandbok: fastställd den 14 februari 1942. Göteborg: Handelshögskolan.

Handelshögskolan i Göteborg, 1956-1964: Katalog. Göteborg: Handelshögskolan. 
Handelshögskolan i Göteborg, 1964-1970: Handelshögskolan i Göteborg. D. 1, Lärare, undervisning, administration. Göteborg: Handelshögskolan.

Harding, Gunnar, 1972: Brev till Arne Lundgren 18/1. Författaren Arne Lundgrens papper, H 2011:12. Göteborg: Göteborgs universitetsbibliotek.

Heurlin, Kaj, 1961: Till hispanisters glädje. Göteborgs Handels-och Sjöfartstidning, 17/4.

Lauritzen, Monica, 1988: Från Hovenäset till Rio. I: Bokfönstret, 16/1. Sveriges Radio.

Lindberg, Bo, \& Nilsson, Ingemar, 1996: Göteborgs universitets historia. 1, På högskolans tid. Göteborg: Rektorsämbetet.

Lindkvist, Peter, 2000: I portugisiska författares sällskap. Göteborgs-Posten, 7/6.

López Serrano, Fernando, 2013: Breve historia de los estudios hispánicos en Suecia. Revista Hispanista Escandinava 2(2). http://journals.lub.lu.se/index. php/rhe/article/view/15791

Lundgren, Arne, 1953: Brev till Per G. Ekström 28/8. Författaren Arne Lundgrens papper, H 2011:12. Göteborg: Göteborgs universitetsbibliotek.

Lundgren, Arne, 1955a: Brev till Per G. Ekström 30/1. Ibid.

Lundgren, Arne, 1955b: Brev till Per G. Ekström 27/3. Ibid.

Lundgren, Arne, 1955c: Brev till FIB:s Lyrikklubb 27/5. Ibid.

Lundgren, Arne, 1955d: Brev till Per G. Ekström odaterat [troligen från hösten 1955]. Ibid.

Lundgren, Arne, 1955e: Brev till Stig Carlson 4/12 Ibid.

Lundgren, Arne, 1956a: Brev till Stig Carlson 9/10. Ibid.

Lundgren, Arne, 1956b: Brev till Artur Lundkvist 21/11. Ibid.

Lundgren, Arne, 1956c: Brev till Stig Carlson 22/11. Ibid.

Lundgren, Arne, 1956d: Brev till Per G. Ekström 20/12. Ibid.

Lundgren, Arne, 1957a: Brev till Ernesto Dethorey 5/4. Ibid.

Lundgren, Arne, 1957b: Brev till Sverker Göransson 16/5. Ibid.

Lundgren, Arne, 1958: Brev till Carl Björkman 29/9. Ibid.

Lundgren, Arne, 1959a: Brev till Styrelsen för Artur Lundkvists stiftelse för översättning av svensk litteratur 18/3. Ibid.

Lundgren, Arne, 1959b: Brev till Sven Bjellerup 21/7. Ibid.

Lundgren, Arne, red., 1961: Fem brasilianska poeter. Stockholm: Norstedt.

Lundgren, Arne, 1963: Brev till Per G. Ekström 22/3. Författaren Arne Lundgrens papper, H 2011:12. Göteborg: Göteborgs universitetsbibliotek.

Lundgren, Arne, 1964: Brev till Adamaria Terziani 30/6. Ibid. 
Lundgren, Arne, 1967: En bakgrund, rekonstruerad. I: Tryckpunkter: 23 Norstedtförfattare i egen sak. Stockholm: PAN/Norstedt. 123-136.

Lundgren, Arne, 1968a: Brev till Georg Svensson 10/1. Författaren Arne Lundgrens papper, H 2011:12. Göteborg: Göteborgs universitetsbibliotek.

Lundgren, Arne, 1968b: Brev till Carl Magnus von Seth 24/3. Ibid.

Lundgren, Arne, 1969a: Brev till Albert Bonniers förlag 17/4. Ibid.

Lundgren, Arne, 1969b: Brev till Bo Setterlind 5/7. Ibid.

Lundgren, Arne, 1970a: Brev till Stig Carlson FIB:s lyrikklubb 16/3. Ibid.

Lundgren, Arne, 1970b: Brev till León Sánchez Cuesta 31/5 Ibid.

Lundgren, Arne, 1981a: Brev till förlaget Nordan 26/3. Ibid.

Lundgren, Arne, 1981b: Brev till Silvia Ribeiro, förlaget Nordan 25/8. Ibid.

Lundgren, Arne, 1994: Brev till Margareta Ahlberg och Alexander Fernandes [odaterat, troligen maj 1994]. Ibid.

Lundgren, Arne, 1996: Brev till José Blanco, Fundação Calouste Gulbenkian 2/5. Ibid.

Lundgren, Arne, 2001: Arne Lundgren: författare. I: Quirin, Bertil (red.), Bohuslän i svartvitt: fotografier och berättelser från det gångna seklet. Kärna: B. Quirin. 160-169.

Lundkvist, Artur, 1955: Brev till Arne Lundgren 5/8. Författaren Arne Lundgrens papper, H 2011:12. Göteborg: Göteborgs universitetsbibliotek.

Michaëlsson, Karl, 1956: Språken vid Handelshögskolan. I: Jonasson, Olof (red.), Ekonomiska och juridiska studier tillägnade Hadar Berglund på hans sextiofemårsdag den 6 mars 1956. Göteborg: Gumperts förlag. 65-72.

Nilsson, Ingemar, 1996a: Göteborgs universitet 1891-1995: data över professorer, docenter, avhandlingar och befordringsärenden. 2. Göteborg: Rektorsämbetet.

Nilsson, Ingemar, 1996b: Göteborgs universitets historia. 2, Ett växande universitet. Göteborg: Rektorsämbetet.

Olsson, Claes-Olof, 2007: Hedersdoktorer vid Göteborgs universitet under 100 år. Göteborg: Göteborgs universitet.

Prekel, Claire de. 2015. L'Archive du lundi n6. Cent ans d'hispanisme en Sorbonne. 1/12. https://ieh.hypotheses.org/114

Riksföreningen för lärarna i moderna språk. 1946-1948: [1945; 1946; 1947]. Bromma: Riksföreningen.

Rodríguez López, Carolina, 2008: Las universitarias. I: López-Ríos, Santiago \& González Cárceles, Juan Antonio (red.), La Facultad de Filosofía y Letras de Madrid en la Segunda República: Arquitectura y Universidad durante los años 30. Madrid: Sociedad Estatal de Conmemoraciones Culturales. 474-491.

Rosengren, Per, 1999: Matilde Westberg. El Pais, $3 / 5$. 
Svenskt översättarlexikon. u.å: Bibliografi - Arne Lundgren. http://www.oversattarlexikon.se/listor/avoversattare/Arne_Lundgren [2017-08-04]

Svensson, Anna. 2008: Borges en Gotemburgo: sobre su conferencia "La Literatura Fantástica" y sus contactos con el Instituto Iberoamericano. Anales N. E. 11. 25-47.

Svensson, Anna, 2018: Mistral och femton böcker. I: Castro, Andrea, Jiménez Tornatore, Eduardo \& Söhrman, Ingmar (red.), Desde Chile a Suecia: caminos culturales por Latinoamérica y Europa: festskrift till Álvaro Foresti. Göteborg: Göteborgs universitet, Institutionen för språk och litteraturer. 93-108.

Söderlund, Börje, 1949: PM 25/5. Utrikesdepartementet 1920 års dossiersystem 1918-1952, I 347. Stockholm: Riksarkivet.

Söhrman, Ingmar, 2016: Romanska språk. I: Personliga tillbakablickar över ämnesområden vid Göteborgs universitet, 4. Göteborg: Seniorakademien vid Göteborgs universitet. 44-53.

Telles, Lygia Fagundes, 1963: Brev till Arne Lundgren 6/1. Författaren Arne Lundgrens papper, H 2011:12. Göteborg: Göteborgs universitetsbibliotek.

Tranströmer, Tomas, 1957: Brev till Arne Lundgren [u.d.] april. Ibid. 